\title{
On Aesthetic Pursuit of Verdi's Opera Creation from the Overture of Nabucco
}

\author{
Ni Ma \\ Xi'an Shiyou University, Xi'an Shaanxi, 710065, China
}

Keywords: Verdi, Opera, Nabucco, Overture, Aesthetic Pursuit.

\begin{abstract}
This article aims to introduce and discuss the overture of Verdi's opera Nabucco. Nabucco is the most representative piece in Verdi's early opera creations, and it is also a work that made him famous. There are milestones in the history of opera and music. This article takes the prelude of the opera Nabucco as the research object, tries to make an objective and comprehensive analysis of the prelude, and summarizes its artistic features.
\end{abstract}

\section{Introduction}

Giuseppe Verdi was born in Longkolole village in Buccetto, Parma province, Italy. He created 26 operas in his lifetime. Nabucco is Verdi's third opera. His work established his place in the opera music scene and he gained reputation.

\section{Introduction to Nabucco Overture and Its Historical Position}

Nabucco was originated from the script of the La Scala theatre ballet in 1838. It is based on the biblical plots. It mainly reflects the Italian nationalist movement. The opera shows the Italian society in the splittist war and the living conditions of the enslaved Jewish people in this real society, the musical mood of the entire opera is passionate. When the audience saw the efforts in the works received persecution, they immediately thought of the oppression of the Italian people and contacted their own experience. It rose and resonated. The rhythm is bright and clear, the rhythm is bold and powerful, the momentum is magnificent, the melody is passionate, and the spirit of patriotism is filled from beginning to end. The moving melodies and distinctive styles are often impressive. Verdi will be profound to the motherland. Feelings and intense hate for the exploiters' aggressors were thoroughly poured into this Nabucco music. In addition to the dramatic moving scenes in Nabucco, the well-known and popular choral song "Flying, Thinking, Riding the Wings of the Singing" became a classic spread around the world and even became an Italian. In the face of the symbol of unyielding spirit displayed by the aggressors, it can also be said that the Italian people are eager for independence. This work once caused a sensation in Milan. It profoundly expressed the Italian nation's quest for light and liberation and its desire to escape the oppression. Verdi also became the Italian nation's glory and pride.

\subsection{Creation background}

The opera Nabucco described above mainly describes the events of the Jews being defeated by Nabucco (Nebuchadnezzar II) and expelled from their homes by the King of Babylon.

When Verdi's comedy was defeated and criticized, he suffered a total blow to the confidence of his creation and decided to stop writing opera.

When Italian composers () and () were already famous, Verdi was still hitting the wall. His life was very unsatisfactory. He first worked as a teacher at Busetto Music School and his life was very tight. He later took the Milan Conservatory and was rejected for various reasons. The income of the first opera alone cannot support him at all, so it is difficult for him to live in a difficult life. At this time, the manager of the La Scala Theatre () invited Verdi to create a tune for (). Verdi did not accept the invitation at first, but then there was a dramatic change in the culprit, after careful consideration after repeated psychological struggles, he finally decided to accept the invitation to create the song. 
After Verdi accepted the invitation to complete the composition in the fall of 1841, began production in March 1842 and performed at the Teatro La Scala in Milan. This work also became his first immortal creation. The play was Nabucco (), who played the king of Jerusalem () was (), and Nabucco 's eldest daughter Abigaille was (), who played the second daughter ( ) is (). Among them, the protagonist of the mezzo-soprano in the play later became his second wife. This work presents the audience with a patriot's attachment to the motherland, and also expresses the tenacious will and determination of the patriots to resist the enemy and fought bravely.

\subsection{Synopsis}

The opera was a total of four acts. It was staged in 1842. The script was written by Solera. The character Nabucchi was Nebuchadneza, the king of Babylon. The king was a brutal aggressor and he led the army to drive Jerusalem away. The Jews seized the opportunity to occupy Jerusalem. The play enthusiasm sang the tenacious will and spirit that the aggressed Jews actively resisted and refused to be enslaved. It also expressed the true feelings of the Jews who missed their hometown and missed their motherland. It is this eternal value of patriotism in the script that deeply touched Verdi. He also thought of his own country and people because Italy was also suffering from Austria's aggression and exploitation. He devoted all his deep feelings for the motherland and strong hatred for the invaders to the music of this opera. Therefore, the tone of the entire opera is passionate, passionate, magnificent, melodic and rhythmical, full of patriotic passion.

The specific storyline is: The story happened in 587 BC, () defeated Jews and entered Jerusalem. The nephew of the King of Jerusalem captured the second daughter of Nabucco (the king of Babylon) and was hiding in the city of Jerusalem, forcing Nabucco to withdraw, but the two fell in love. Ismailyeh persuaded Fenegna to flee, otherwise it would be life-threatening. At this time, Nabucco's eldest daughter () led a group of Babylonians into the temple and admired Abegayle of Ismail Yerelie for pouring love to Ismayer, but was rejected. After the king of Babylon had conquered Jerusalem, Nabco captured the Hebrews to Babylon. The king was imprisoned for his madness, and Nabucco's eldest daughter, Abigail, took the opportunity to win power under the support of the priests and others. And Abigail was planning to kill his sister Fenegna and at the same time slaughtered the sacrifices of the Jews to the Lord God. King Nabucco glimpsed in the prison. The second woman, Fenegna, was tied to the executioner and headed to Jesus. Prayer, hoping to get help. At this moment, the king's mind became sober and immediately armed with a sword. He led his guards to rescue Fenegna, shattered the main deities, and released all Jews. The eldest daughter Abigail Eileen was guilty of committing suicide. Nabucco regained control of the country. Nabucco also became God's servant, the king of the kings. Fenegna and Ismailyeh are married, and the king of Babylon declares the faith of the Jewish god, Jesus.

\subsection{Historical position and contribution}

In the author's opinion, an excellent work often leads the audience's vision to a new and wider field or leads to a deeper level behind the work. Verdi's opera has such a potential. This work also paved the way for Willdi to become famous in the future, which laid the foundation for his future position in the opera industry.

As stated at the beginning of the article, the opera "Nabucco" has laid a solid foundation for Verdi's artistic future and also marks Verdi's operatic creation to be truly on track. The powerful music expresses the inner feelings of the Italian people, inspires the Italian national spirit, stimulates Italian patriotism, and expresses the people's yearning for freedom. The melody of the work is beautiful, impressive, emotional, and inspiring. The rhythm is strong and consistent with the tastes of the people at that time. The singer is highly praised and has become the revolutionary song of the people. In music technology, the composers deliberately made the orchestra dramatic, allowing the band to fully embody the artistic image, organically melding the vocal and orchestral parts together, which are unique in the creation. The music in the play has a good connection between the character and emotions and the conflict between the plot and the story. It also served as a model for his later creation. 
The success of Nabucco achieved the desire of Verdi's longing for the national liberation of the motherland. The magnificent and tragic spirit conveyed by the work and the spirit of inspiring people always inspired the Italian people and strongly expressed the Italian people's independence. Really long for.

In short, both from the ideological content of the work and from the technical design of the work, Verdi set a new image and opened the way for his later creation. It was a milestone in his creative career. masterpiece.

The choral song in Nabucco is of great significance, organically connected with the plot, and organically integrated with the content of the drama. The simple and rigorous chorale is also commendable. Of course, this work also has its shortcomings: The repertoire is poor and the orchestra is too heavy. Filled with brass sound, the marching rhythm is too rhythmic. The passion and drama embodied in the work can lack his proud place. In terms of the vitality and simplicity of the music language, it is second to none in terms of the integrity and power of the artistic conception.

\subsection{The Musical Form of the Overture of Opera Nabucco}

The overture is one of the oldest instrumental genres, specifically the instrumental music that was performed before the official start of the opera, the ballet, and the oratorio. The main role of the opera's prelude is to give emotional improvisations or believings for the upcoming operas, some foreshadowed the emergence of the opera's musical themes, and some may serve to summarize the content of the opera. Because it is short and wonderful, it concentrates on the essence of opera music and often plays on symphonic music, becoming an important form of music.

The orchestra of the opera Nabucco overture is prepared as follows: two flute or plus piccolo, two oboe or Canadian tube, two clarinets, four French numbers, two small numbers, and three ministerial numbers (two treble-bass), A squat bass, timpani, drum, cymbal, snare, triangle, and two harp.

\subsection{The Selection and Use of Woodwind Instruments in Overture}

Although mainly in vocal form, the role of the orchestra is not overlooked, but the color and expressiveness of the orchestra are greatly enhanced. The two complement each other and jointly reveal theatrical conflicts and character emotions.

Since the second half of the nineteenth century, Italy has pursued a kind of realistic literary trend of thought. Verdi is also unavoidably affected by this trend of thought. In his creative practice, he has "a strong dramatic conflict and profound The character's heart has obvious manifestation. Pay attention to the performance of music and the close cooperation between the creation of music and the story. In terms of structure, the works generally preserve the principle of the structure of divisional music in the music creation of the Classical period, and the divisions and fields are not fragmented and incoherent, and are not decisively separated. Instead, they are the organic combination of the two. It is also part of a dramatic overall development. The huge scale of the orchestra has created a magnificent and spectacular scene, which has deeply attracted the attention of the audience and caused the audience to have a strong inner resonance, with strong personal characteristics.

Verdi is an opera composer who stands at the pinnacle of the world's operatic arts in the 19th century. His outstanding contribution to the opera art is indelible. Verdi belongs to his time, but no doubt, he is for the opera art. The glory will pass through time and space, and shines upon the entire human race.

\section{The Aesthetic Pursuit of Verdi's Opera Creation from the Overture of Nabucco}

Verdi is Italy's greatest opera composer. His career actually constituted the history of Italian music in the latter part of the 19th century. His career spanned a long period of 54 years. He never broke with Italian opera traditions. Without abandoning Italy's rich and long musical tradition, he firmly believes that every country should develop its own unique style of national art, and should not blindly accept foreign influences, and not follow the wave of fashion, and the foreign things he accepts are all 
digested. The study of the achievements of French and German music, fully integrated into its own part of the music language, is an art that expresses human nature and deals well with the relationship between inheritance and innovation. The late work "Falstaff" can be said to be self-confident laughter insisting on his own aesthetic creation.

Specifically, we observe the aesthetic pursuit of Verdi's opera creation from the prelude to the opera Nabucco.

I think there are so many characteristics: 1 . A clear sense of the times and a profound embodiment of human care. 2. Reflects a holistic idea of opera creation. Verdi's creations are organically blended with drama, music, chorus, etc., with the dominant motivation of opera music. 3. Everywhere reflects the reality of life. From the early description of heroes and myths, to the intense attention to real life and the care for lively humanity. 4. Attachment and expectation to the homeland.

Verdi is very concerned about the destiny of the country and the nation, and has a strong patriotic enthusiasm. His works also reflect his feelings about the nation and the use of the national language materials.

Verdi is an opera composer who stands at the pinnacle of the world's operatic arts in the 19th century. His outstanding contribution to the opera art is indelible. Verdi belongs to his time, but no doubt, he is for the opera art. The glory will pass through time and space, and shines upon the entire human race.

The opera is a drama that uses music to tell the story, and more precisely, it uses the human voice to interpret the process of the opera.

\section{References}

[1] Barbara Mayer. Translated by Zhang Xiaojing. Verdi, Beijing: People's Music Publishing House, 2004

[2] Paul Robinson. Translated by Zhou Bingbing. Opera and concept - From Mozart to Strauss, Shanghai: East China Normal University Press, 2008.

[3] Ding Yi. Western famous opera series (Vol.1) [M]. Beijing: International Culture Publishing Company, 2002.

[4] Liu Shiyu, Zhang Ning. Verdi, the designer of Opera Palace, Beijing: New World Press, 1998.

[5] Zhang Xian, Xu Guobi, Shen Wenkai, An Shaoshi. Western opera masterpieces commentary, Beijing: People's Music Publishing House.1992.

[6] Qian Yuan, Lin Hua. Introduction to Opera, Shanghai: Shanghai Music Publishing House.2003.

[7] Yu Dugang. Vocal Art Aesthetics, Beijing: People's Music Publishing House.2005.

[8] Liu Shirong. Opera master Verdi, Shanghai: Shanghai People's Publishing House.1999.

[9] Zhang Yunqing. Opera Music Analysis, Beijing: Higher Education Press.2004. 